\title{
ERRATUM
}

\section{Rivers, Oceans, and Spirits: Water Cosmologies, Gender, and Religious Change in Southeast Asia - ERRATUM}

\section{Barbara Watson Andaya}

doi: http://dx.doi.org/10.1017/trn.2016.2, Published by Cambridge University Press, 1 June 2016.

The above publication, "Rivers, Oceans, and Spirits: Water Cosmologies, Gender, and Religious Change in Southeast Asia” by Barbara Watson Andaya, originally published without an abstract or keywords. The article has since been updated to reflect the correct abstract and keywords in print and online. The editors apologize for this error and any confusion this omission may have caused.

\section{Reference}

Andaya, Barbara Watson. 2016. Rivers, Oceans, and Spirits: Water Cosmologies, Gender, and Religious Change in Southeast Asia. Trans-Regional and-National Studies of Southeast Asia 4(2). doi:10.1017/trn.2016.2. 